\title{
Cultivation of Crops and Wild Relatives in the Genus Avena L. (Poaceae) in the Georgia (South Caucasus)
}

\author{
Maia Akhalkatsi ${ }^{1 *}$, Annette Otte ${ }^{2}$, Tamar Goloshvili ${ }^{1}$, Tamar Girgvliani ${ }^{1}$ and Lamar Mazanishvili ${ }^{1}$ \\ ${ }^{1}$ Department of Plant Genetic Resources, Institute of Botany, Ilia State University, Georgia \\ ${ }^{2}$ Division of Landscape Ecology and Landscape Planning, Institute of Landscape Ecology and Resources Management, Justus-Liebig University, Germany
}

Submission: September 17, 2018, Published: September 26, 2018

"Corresponding author: Maia Akhalkatsi, Head of Department of Plant Genetic Resources, Institute of Botany, Ilia State University, Faculty of Natural Sciences and Engineering, K Cholokashvili 3/5, 0162 Tbilisi, Republic of Georgia; Tel: +995 599193529; Email: maia_akhalkatsi@iliauni.edu.ge

\section{Abstract}

Avena L. crops are cultivated in agriculture as 3 species in Georgia: A. sativa, A. sativa var. aurea and A. sativa var. krausei. The uses of the crop wild relatives (CWR) are total related to species of direct socio-economic importance, which includes the progenitors of crops. Accepted name of Avena are 6 species in Georgia and these have many synonyms as 25 species. CWRs are to 4 species: A. fatua, A. sterilis subsp. ludoviciana, A. sterilis and A. barbara, and these are with GP-1B and TG-1B. Other Avena are of 2 species: A. clauda and A. ventricosa in Georgia and these are not for cultivated crops and they have GP-3 and TG-3. A. fatua and A. sterilis subsp. ludoviciana are for cultivated of crops as A. sativa. These are with chromosomes of genes $2 \mathrm{n}=42 / 48$. A. barbara is making as cultivated of crops as A. sativa var. aurea, which is in Svaneti, Meskheti and Tusheti. A normal chromosome is in of genes $2 \mathrm{n}=14 / 28 / 32 / 42$. A. sterilis has storage of varieties for A. sativa var. krausei and it has genes $2 \mathrm{n}=28 / 42$. Two species: $A$. clauda and $A$. ventricosa has small genes $2 \mathrm{n}=14$. All species has height, length, leaf and flowers of the ground.

Keywords: Avena cultivated crops; CWRs; Chromosomes of genes; Accepted; Synonyms

\section{Introduction}

The genus Avena L. (Poaceae) includes cultivated species with different ploidy levels and a number of wild species reflecting a wide range of botanical and ecological diversity. With this in view, oat species became the subject of investigations to specify the complex organization of the Avena genus and indicate aspects of its evolution and phylogenetic links between the species. Oats - Avena sativa L. was cultivated in Georgian regions and mainly used as forage [1]. These crops are a traditionally cultivated plant distributed from 400 to $1400 \mathrm{~m}$ a.s.l., and present, it is cultivated only in high mountain regions from $1000-1800 \mathrm{~m}$ a.s.l. It is used only as forage for horses and poultry. This mountain area is used as forage plant. The origin of seed material is unknown.

The local population is purchasing the seeds in the market and receives no information or instructions on its origin. Several varieties are described in Upper and Lower Svaneti: A. sativa. It is used only as forage for horses and poultry. Two varieties of oats have been described for Upper Svaneti, Meskheti and Tusheti: A. sativa var. aurea Körn. and A. sativa var. krausei Körn. [2,3]. A. sativa var. aurea is as in Germany and America. It is purchased in the market and farmers receive no information about their origin. Oat is one of the most important cereal crops in the world. A majority of these forms came from the centers of origin, which by definition shows great diversity of Avena species. Further search for agronomical traits and utilization of new oat breeding sources is very important for breeding purposes.

The crop wild relatives (CWRs) of Avena are related taxa to species of direct socio-economic importance, which includes the progenitors of crops. CWRs are restricted only to species related to cultivated crops, including such important field crops as oats - A. sativa and industrial crops. Wild oats are perpetual invaders of cereal fields in Caucasus and elsewhere. Wild species found in the Georgia are A. fatua, A. ludoviciana, A. barbata, which are considered participated in speciation process [4].

Georgia CWR of Avena is often encountered as weeds in ruderal areas and therefore, ex situ conservation of seed may prove the more effective conservation methodology. CWR of 8 species are considered as synonyms or subspecies of crops by some authors. Avena of 8 species are the same as medicinal crops: vitamins B1, B2, B3, B6, E. We have very little information on this species, but it should be possible to grow it as a spring sown annual in Georgia and might also succeed as an autumn-sown crop.

A. fatua species, one report says that it is possibly a subspecies of A. ludoviciana and is often cultivated for its edible seed in 
warmer temperate zones [5,6], whilst some modern works see it as no more than a synonym of $A$. sativa. Rural vegetation is one of the most interesting in terms of CWR. Especially, field crop wild relatives occur in this biome. Although this point has often been made in the context of CWR conservation [7-9], it should not entirely negate the implementation of in situ conservation activities both inside and outside of formal protected areas as discussed above.

We have several species of Avena in Georgia and many are as synonyms and we have some accepted name. The importance of this project is determined by ability of CWR to exchange genes with the crops. CWR germplasm is used to improve production and food quality of cultivars originated previously due to domestication of crop ancestor species. CWRs have already made substantial contributions to improving food production through the useful genes that they contribute to new crop varieties. They have provided resistance to pests and diseases in a wide range of crops. The genes that come from CWR and other wild plants make a direct contribution to increased human wellbeing through improving agricultural production and maintaining sustainable Agro-Ecosystems. Therefore, the effective conservation and sustainable use of CWRs are essential elements for increasing food security, eliminating poverty and maintaining a healthy environment.

\section{Materials and Methods}

\section{Plant material}

Crop wild relatives (CWRs) are wild plant species closely related to crops, including wild ancestors. There are an accepted name of 3 crops and 6 CWRs of Avena as naturalized species and in Georgia. Avena are crops:
a. A. sativa L.
b. A. sativa var. aurea Körn
c. A. sativa var. krausei Körn

CWRs are of Avena:
a. A. barbata Pott. ex Link
b. A. clauda Durieu
c. A. fatua L.
d. A. sterilis $L$.
e. A. sterilis subsp. ludoviciana (Durieu) Gillet \& Magne
f. A. ventricosa Balansa.

Flora Georgian has other 7 and 8 species of Avena from Makashvili A, Sosnovski L [10] and Ketskhoveli N [2]. Many of species are as synonyms and some are as accepted name:

a. A. pilosa M. Bieb. is a synonym of A. clauda Durieu

b. A. barbata Pott. is an accepted name

c. A. sativa L. is an accepted name d. A. fatua L. is an accepted name

e. A. meridionalis (Malzev) Roshev. is a synonym of $A$. fatua

L.

f. A. trichophylla K. Koch is a synonym of A. sterilis subsp. ludoviciana (Durieu) Gillet \& Magne

g. A. sterilis L. is an accepted name

h. A. ludoviciana Durieu is a synonym of A. sterilis subsp. ludoviciana (Durieu) Gillet \& Magne.

Avena crops of 2 species are from Ketskhoveli N [2]:

a. A. sativa var. aurea Körn.

b. A. sativa var. krausei Körn.

Flora of Caucasus is from Grossheim AA [8] and has many species of the Avena in Georgia. These species are in Caucasus and if it is not in Georgia and this is as synonym and other accepted name of Avena species are from this place:

a. A. clauda Durieu is an accepted name

b. A. pilosa M. Bieb. is a synonym of $A$. clauda Durieu

c. A. bruhnsiana Gruner is a synonym of A. ventricosa Balansa

d. A. barbata Pott. is an accepted name

e. A. wiestii Steud. is a synonym of $A$. barbata Pott. ex Link.

f. A. meridionalis (Malzev) Roshev. is a synonym of $A$. fatua

L.

g. A. macrantha (Hack.) Malzev is a synonym of A. sativa L.

h. A. fatua L. is an accepted name

i. A. sativa L. is an accepted name

j. A. ludoviciana Durieu is a synonym of A. sterilis subsp. ludoviciana (Durieu) Gillet \& Magne

k. A. trichophylla K. Köch is a synonym of A. sterilis subsp. ludoviciana (Durieu) Gillet \& Magne

I. A. sterilis $L$. is an accepted name.

Agrarian crops and wild fruit resources was determined as the accepted Latin names and these species has different names for as synonyms and subspecies. Linking phenotypes is very much to the usefulness of good molecular characterization, together forming the basis of progress in modern genomics research in crop plants. It will be to determine which varieties and species of crops and fruits are cultivated in alpine zone as the upper limit till the location of $1800 \mathrm{~m}$ a.s.l. In the classification, wild species were used both as two groups and in other calculation as separate cultivars.

\section{Methodology}

Genus Avena involves natural CWR species diversity. According to this concept three Gene Pools (GP) are distinguished as follows: 
Primary Gene Pool (GP-1) within which GP-1A are the cultivated forms and GP-1B are the wild and weedy forms of the crop. Secondary of Gene Pool (GP-2) which includes the coenospecies (less closely related species) from which gene transfer to the crop is possible but difficult using conventional breeding techniques. Tertiary Gene Pool (GP-3) which includes the species from which gene transfer to the crop is impossible, or if possible requires sophisticated techniques, such as embryo rescue, somatic fusion or genetic engineering.

The taxon group concept is used to establish the degree of CWR relatedness of a taxon. Application of the taxon group concept assumes that taxonomic distance is positively related to genetic distance. CWR rank of taxon groups according is defined as follows:

a. Taxon Group $1 \mathrm{~A}(\mathrm{TG}-1 \mathrm{~A})$ is a crop.

b. Taxon Group 1B (TG-1B) is same species as crop.

c. Taxon Group 2 (TG-2) is same series or section as crop.

d. Taxon Group 3 (TG-3) has same subgenus as crop. e. Taxon Group 4 (TG-4) has only same genus.

f. Taxon Group 5 (TG-5) is same tribe but different genus to crop.

\section{Statistical analyses}

Agrarian crops and wild fruit resources was determined as the accepted Latin names and these species has different names for as synonyms and subspecies. Molecular characterization is very much linked to the usefulness of good, together forming the basis of progress in modern genomics research in crop plants. It will be to determine which varieties and species of crops and fruits are cultivated in Mounties as coordinates and the upper limit till the location $1900 \mathrm{~m}$ a.s.l. STATISTICA 6.0 software was used for cluster analysis. this method uses an analysis of variance approach to evaluate the distances between clusters. This attempts to minimize the Sum of Squares of any two (hypothetical) clusters that can be formed at each step. The distance measure interval is Euclidean distance, computing distances between objects in a multidimensional space. These three analyses were performed using the software package SPSS Statistics 16.0, PC-ORD 5.33 and Statistica 6.0 , respectively.

Results

\section{Avena species cultivated crops}

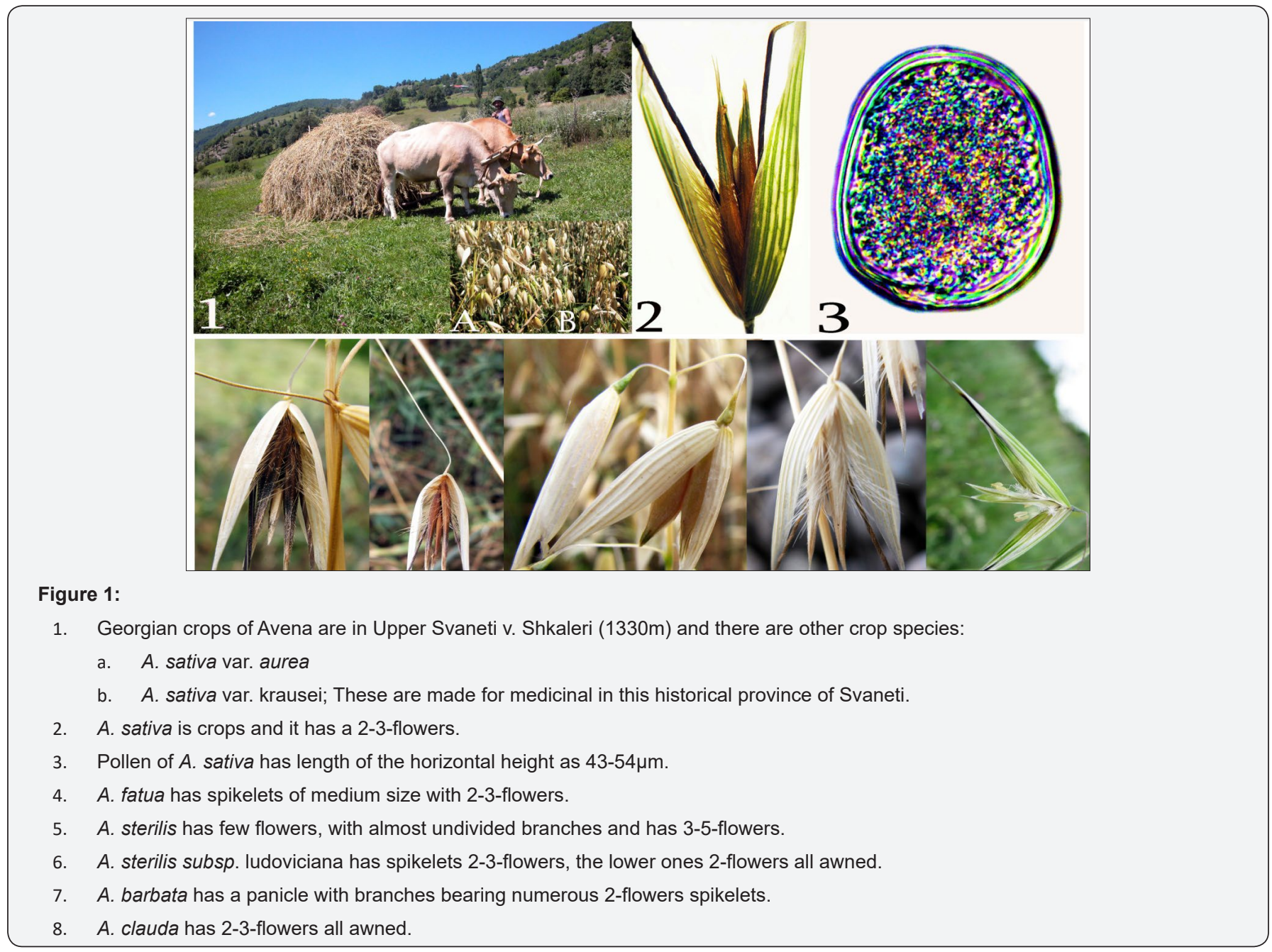


Table 1: Avena species are in different heights in Georgia: location with coordinates with degrees and minutes, elevation with above sea level in meters $(\mathrm{N}=9)$.

\begin{tabular}{|c|c|c|c|c|}
\hline S.N & Avena species & Location & Coordinates & Elevation \\
\hline \multirow{2}{*}{1} & \multirow{2}{*}{ Avena barbata } & \multirow{2}{*}{$\begin{array}{l}\text { Kartli, Lower Kartli, Outer Kakheti, Kiziki, Gardabani, Javakheti, } \\
\text { Meskheti }\end{array}$} & $\mathrm{N} 41^{\circ} 13^{\prime} / 41^{\circ} 32^{\prime}$ & \multirow{2}{*}{$325-1734 m$} \\
\hline & & & E $42^{\circ} 55^{\prime} / 46^{\circ} 33^{\prime}$ & \\
\hline \multirow{2}{*}{2} & \multirow{2}{*}{ Avena clauda } & \multirow{2}{*}{$\begin{array}{l}\text { Dedoplistskaro in Outer Kakheti, Kiziki, Lower Kartli, Gardaba- } \\
\text { ni }\end{array}$} & $\mathrm{N} 41^{\circ} 17^{\prime} / 41^{\circ} 27^{\prime}$ & \multirow{2}{*}{$410-721 \mathrm{~m}$} \\
\hline & & & E $45^{\circ} 48^{\prime} / 46^{\circ} 11^{\prime}$ & \\
\hline \multirow[t]{2}{*}{3} & \multirow[t]{2}{*}{ Avena fatua } & \multirow{2}{*}{$\begin{array}{l}\text { South and North and West and East Georgia; Abkhazeti, Svane- } \\
\text { ti, Adjara, Imereti, Kartli, Javakheti, Meskheti }\end{array}$} & N $41^{\circ} 21^{\prime} / 43^{\circ} 25^{\prime}$ & \multirow[t]{2}{*}{$169-1800 \mathrm{~m}$} \\
\hline & & & E $41^{\circ} 36^{\prime} / 45^{\circ} 15^{\prime}$ & \\
\hline \multirow{2}{*}{4} & \multirow{2}{*}{ Avena sativa } & \multirow{2}{*}{ South and North and West and East Georgia } & $\mathrm{N} 40^{\circ} 52^{\prime} / 43^{\circ} 03^{\prime}$ & \multirow{2}{*}{$400-1400 \mathrm{~m}$} \\
\hline & & & $\mathrm{E} 41^{\circ} 48^{\prime} / 46^{\circ} 04^{\prime}$ & \\
\hline \multirow{2}{*}{5} & \multirow{2}{*}{ Avena sativa var. aurea } & \multirow{2}{*}{ Upper Svaneti, Javakheti, Meskheti, Tusheti } & $\mathrm{N} 41^{\circ} 21^{\prime} / 42^{\circ} 23^{\prime}$ & \multirow{2}{*}{$900-1900 \mathrm{~m}$} \\
\hline & & & $\mathrm{E} 42^{\circ} 35^{\prime} / 45^{\circ} 39^{\prime}$ & \\
\hline \multirow{2}{*}{6} & \multirow{2}{*}{ Avena sativa var. krausei } & \multirow{2}{*}{ Upper Svaneti } & $\mathrm{N} 42^{\circ} 59^{\prime} / 43^{\circ} 03^{\prime}$ & \multirow{2}{*}{$800-1350 m$} \\
\hline & & & $\mathrm{E} 42^{\circ} 34^{\prime} / 42^{\circ} 63^{\prime}$ & \\
\hline \multirow{2}{*}{7} & \multirow{2}{*}{ Avena sterilis } & \multirow{2}{*}{ Abkhazeti, Western Transcaucasia } & $\mathrm{N} 43^{\circ} 17^{\prime} / 43^{\circ} 25^{\prime}$ & \multirow{2}{*}{$850-1340 \mathrm{~m}$} \\
\hline & & & E $40^{\circ} 12^{\prime} / 40^{\circ} 22^{\prime}$ & \\
\hline \multirow[b]{2}{*}{8} & \multirow[b]{2}{*}{ Avena sterilis subsp. Ludoviciana } & \multirow{2}{*}{ Imereti, Lower Kartli, Gardabani, Javakheti, Meskheti, Kakheti } & $\mathrm{N} 41^{\circ} 34^{\prime} / 42^{\circ} 03^{\prime}$ & \multirow{2}{*}{$504-1400 \mathrm{~m}$} \\
\hline & & & E $43^{\circ} 10^{\prime} / 44^{\circ} 59^{\prime}$ & \\
\hline \multirow[b]{2}{*}{9} & \multirow[b]{2}{*}{ Avena ventricosa } & \multirow[b]{2}{*}{ Javakheti, Meskheti } & $\mathrm{N} 41^{\circ} 21^{\prime} / 41^{\circ} 36^{\prime}$ & \multirow[b]{2}{*}{$1325-1795 m$} \\
\hline & & & $\mathrm{E} 42^{\circ} 54^{\prime} / 43^{\circ} 26^{\prime}$ & \\
\hline
\end{tabular}

Wild relative of cultivated Avena sativa, A. sativa var. aurea and A. sativa var. krausei (Poaceae) are in Georgia and it has from old period (Table 1). A. sativa var. aurea and A. sativa var. krausei are in Upper Svaneti and from old periods. Georgian crops of Avena are in Upper Svaneti Village Shkaleri and there are two crop species: A. sativa var. aurea and A. sativa var. krausei (Figure 1). These are made for medicinal in this historical province of Upper and Lower Svaneti. A. sativa var. aurea is as in Tusheti, Meskheti and Javakheti (Table 1). Oats - A. sativa is occupies very small area among crop fields in a traditionally cultivated plant distributed from 300 to $1800 \mathrm{~m}$ a.s.l. in South, North, West and East Georgia (Table 1). It is used only for horses and poultry in mountain areas of cattle breeding and is used as forage plant. Two varieties of oats have been described for Upper Svaneti: A. sativa var. aurea and A. sativa var. krausei 400 to $1400 \mathrm{~m}$ a.s.l. Oats - A. sativa var. aurea is in Tusheti and Meskheti from 1800 to $1900 \mathrm{~m}$ a.s.l. (Table 1).

Wild relative of cultivated species has accepted, and other species are as synonyms: A. A. sativa is an accepted name and synonyms are:
a. A. macrantha (Hack.) Malzev
b. A. sativa var. contracta Neilr
c. A. sativa var. glaberrima (Thell.) Malz
d. A. sativa var. nuda (L.) Körn
e. A. sativa var. pilosa (Koeler) Tab. Morais

f. A. verna Heuze. B. A. sativa var. aurea Körn. is an accepted name in Georgia and CWR for this is A. barbata Pott. ex Link. C. A. sativa var. krausei Körn. is an accepted name and CWR is A. sterilis L.

Avena cultivated crops are the origin of the seeds material is unknown to local farmers. Genetic diversity in oat (A. sativa) was analyses with a set of 182 accessions collected worldwide. GP and TG are as $1 \mathrm{~A}$ for cultivated crop plants. These crops are for medicinal and they have vitamins B1, B2, B3, B6, D and E. Oats species: A. sativa, A. sativa var. aurea and A. sativa var. krausei, have a low chromosome number for genes $2 \mathrm{n}=42 / 48$ (Table 2 ).

The origin of seed material is unknown:

a. A. sativa has a low chromosome number for genes $2 \mathrm{n}=42 / 48$ and length is $60-100 \mathrm{~cm}$ tall, always with $3 \mathrm{crop}$ species, leaf is $25-40 \mathrm{~cm}$ and $2-3$-flowers have $20-25 \mathrm{~mm}$ for species (Figure 1:2,3 \& Table 2). It is in flowers from June to July, and the seeds ripen from August to October. The most optimal temperature is $28-35^{\circ} \mathrm{C}$.

b. A. sativa var. aurea has a low chromosome number for genes $2 \mathrm{n}=42$ and length is $40-100 \mathrm{~cm}$ tall, always with 3 crop species, leaf is $20-30 \mathrm{~cm}$ and 2 flowers are $25-30 \mathrm{~mm}$ for species (Figure 1:1A \& Table 2). Flowers are in long JuneJuly and seeds ripen from August to September. Flowering is favored by wet weather and the temperatures of $20-25^{\circ} \mathrm{C}$. 
c. A. sativa var. krausei has a low chromosome number for genes $2 \mathrm{n}=42 / 48$ and length is $70-100 \mathrm{~cm}$ tall, leaf is as $30-40 \mathrm{~cm}$ and $2-3$-flowers are $40-50 \mathrm{~mm}$ for species (Figure 1:1B \& Table 2). Flowers and seeds are in long June-August. Flowering is favored by wet weather and the temperatures of $20-23{ }^{\circ} \mathrm{C}$.

\section{Avena species CWRs}

We can make some CWRs add variety to species for crops in Georgian regions and in different arias (Figure 1; Table 1 \& 2).
CWRs are 6 species of Avena as accepted name and synonyms are many 25 species. The genesis of cultivated oats is no doubt linked to that of weedy as well as wild species, i.e. A. fatua, A. sterilis subsp. ludoviciana, A. sterilis and A. barbara. Wild oats A. fatua and A. sterilis subsp. ludoviciana, hybridize easily with ordinary oats A. sativa, and thrive under conditions close to cultivated ones, around water, and on uncompacted soils. A. barbata is associated with the crops of $A$. sativa var. aurea and $A$. sterilis accords of $A$. sativa var. krausei.

Table 2: CWRs species of Avena are name of local crops for Georgia. Length $(\mathrm{cm})$, leaf $(\mathrm{cm})$ and flowers $(\mathrm{mm})$ are for species. Chromosome numbers are for genes synonyms species $(2 n=)$. Primery gene pool (GP) and Taxon Group (TG) $1 B$ species as crop. $N=10$.

\begin{tabular}{|c|c|c|c|c|c|c|c|}
\hline S.N & Avena species & $\begin{array}{c}\text { Length } \\
\mathbf{( c m})\end{array}$ & Leaf $\mathbf{( c m )}$ & $\begin{array}{c}\text { Flowers } \\
\mathbf{( m m} \mathbf{~}\end{array}$ & $\begin{array}{c}\text { Chromos-omes } \\
\mathbf{2 n =}\end{array}$ & GP-TG & Name of Local Crops \\
\hline 1 & Avena sativa & $60-100$ & $25-40$ & $20-25$ & $42 / 48$ & GP-1A TG-1A & Avena sativa \\
\hline 2 & A. sativa var. aurea & $40-100$ & $20-30$ & $25-30$ & 42 & GP-1A TG-1A & Avena sativa var. aurea \\
\hline 3 & A. sativa var. krausei & $70-100$ & $30-40$ & $40-50$ & $42 / 48$ & GP-1A TG-1A & Avena sativa var. krausei \\
\hline 4 & Avena fatua & $80-120$ & $30-40$ & $25-45$ & $14 / 28 / 42 / 48$ & GP-1B TG-1B & Avena sativa \\
\hline 5 & $\begin{array}{c}\text { Avena sterilis subsp. } \\
\text { ludoviciana }\end{array}$ & $50-100$ & $40-50$ & $25-30$ & 42 & GP-1B TG-1B & Avena sativa \\
\hline 6 & Avena barbata & $40-100$ & $15-25$ & $25-30$ & $28 / 32 / 42$ & GP-1B TG-1B & Avena sativa var. aurea \\
\hline 7 & Avena sterilis & $70-100$ & $30-40$ & $40-50$ & $28 / 42$ & GP-1B TG-1B & Avena sativa var. krausei \\
\hline 8 & Avena clauda & $30-60$ & $20-$ Aug & $20-30$ & 14 & GP-3 TG-3 & Avena clauda \\
\hline 9 & Avena ventricosa & $30-60$ & $12-0 \mathrm{ct}$ & $25-30$ & 14 & GP-3 TG-3 & Avena ventricosa \\
\hline
\end{tabular}

Some CWRs of 4 species are for making the cultivated crops plants:
a. A. fatua
b. A. sterilis subsp. Ludoviciana
c. A. barbata
d. A. sterilis

These species are considered as accepted name or subspecies of crops by some authors for Georgian Flora species of Avena are as synonyms:

a. A. barbata is an accepted name and synonyms are in Georgia: 1. A. barbata var. atherantha (Presl.) Grossh.; 2. A. barbata subsp. subtypica Malzev; 3. A. barbata var. triflora Trabut.; 4. A. barbata subsp. wiestii (Steud.) Tzvelev; 5. A. nuda subsp. wiestii (Steud.) Á. Löve; 6. A. wiestii Steud.

b. A. fatua is an accepted name and synonyms are: 1 . A. fatua var. intermedia (F. Lestib.) Lej. \& Courtois; 2. A. fatua var. glabrata Peterm.; 3. A. fatua var. pilosissima Gray.; 4. A. fatua L. var. vilis (Wallr.) Hausskn.; 5. A. meridionalis (Malzev) Roshev.

c. A. sterilis subsp. ludoviciana (Durieu) Gillet \& Magne is an accepted name and synonyms are: 1 . A. ludoviciana Durieu; 2. A. ludoviciana var. glabrescens Durieu ex Godr; 3. A. ludoviciana var. macrantha Malz; 4. A. ludoviciana var. psilathera Thell; 5. A. trichophylla K. Köch; d. A. sterilis is an accepted name and synonyms are: 1 . A. macrantha Moench; 2. A. nutans St.-Lag. 3. A. sterilis var. glabriflora Malzev; 4. A. sterilis var. maxima Pérez-Lara; 5. A. sterilis var. media Malzev.

CWRs of 2 species are not making the cultivated crops plants: 1. Avena clauda and 2. Avena ventricosa:

a. A. clauda is an accepted name and synonyms are: 1 . A. clauda var. eriantha Coss. \& Durieu; 2. A. clauda var. leiantha Malz. 3. A. pilosa Aucher ex Durieu.

b. A. ventricosa Balansa is an accepted name and synonym as A. bruhnsiana Gruner. in Meskheti.

The common wild oats, A. fatua and A. sterilis subsp. ludoviciana, are associated with the crops of $A$. sativa. Cultivates of $A$. fatua and A. sterilis subsp. ludoviciana are for crop breeding and evaluation with GP-1B and TG-1B it is for distributed in as CWRs and these has chromosome number for genes of $A$. fatua $2 \mathrm{n}=14 / 28 / 42 / 48$; and A. sterilis subsp. ludoviciana has $2 \mathrm{n}=42$ (Table 2). A. fatua has a length $80-120 \mathrm{~cm}$, leaf $30-40 \mathrm{~cm}$ and $2-3$-flowers of $20-25 \mathrm{~mm}$ are for species (Figure 1:4 \& Table 2). Flowers are in long June-July and seeds ripen from August to October. Sprouting occurs both at low $20-30{ }^{\circ} \mathrm{C}$ and high $28-35{ }^{\circ} \mathrm{C}$ temperatures. A. sterilis subsp. ludoviciana has a length $50-100 \mathrm{~cm}$, leaf $40-50 \mathrm{~cm}$ and $2-3$-flowers of 25-30 mm are for species (Figure 1:6 \& Table 2). Flowers are in long April-June and seeds ripen from Augusts. The most optimal temperature is $15-30^{\circ} \mathrm{C}$. 
A. barbata is associated with the cultivated species crop of $A$. sativa var. aurea and it is for distributed in as CWRs as GP-1B and TG-1B. These has chromosome number for genes of $A$. barbata $2 \mathrm{n}=28 / 42 / 48$ (Table 2). A. barbata has a length $40-100 \mathrm{~cm}$, leaf $15-25 \mathrm{~cm}$ and 2 flowers of $25-30 \mathrm{~mm}$ are for species (Figure 1:7 \&Table 2). Flowers are in April-May and seeds ripen June-July. The most optimal temperature is $15-35^{\circ} \mathrm{C}$. The seed ripens in the latter half of summer and, when harvested and dried, can store for several years.

A. sterilis accords of the cultivated species A. sativa var. krausei. A. sterilis has GP-1B and TG-1B and chromosome number for genes is $2 \mathrm{n}=28 / 42$ (Table 2). A. sterilis has a length $70-100 \mathrm{~cm}$, leaf 30 $40 \mathrm{~cm}$ and 3-5 flowers of 40-50mm are for species (Figure 1:5 \& Table 2). Flowers are in July periods and seeds ripen from Augusts. Optimal temperature is $28-35^{\circ} \mathrm{C}$.

A. clauda is not making the cultivated crops plants. GP-3 and TG-3 it is for distributed in as CWRs. It has a chromosome number for genes is $2 \mathrm{n}=14$ (Table 2). It has a length as $30-60 \mathrm{~cm}$ tall, leaf 8-20 $\mathrm{cm}$ and 2-3-flowers of 20-30 mm are for species (Figure 1:8 \& Table 2). Flowers are in April-May periods and seeds ripen from July. Optimal temperature is $15-35^{\circ} \mathrm{C}$.

A. ventricosa is an accepted name and synonym is $A$ bruhnsiana in Caucasian Flora. It has not as cultivated crops plants GP-3 and TG-3 as CWRs. The chromosome number for genes are as $2 \mathrm{n}=14$ (Table 2). It is as length as $30-60 \mathrm{~cm}$ tall, leaf $10-12 \mathrm{~cm}$ and 2-flowers of $25-30 \mathrm{~mm}$ are for species. Flowers are in MayJune periods and seeds ripen from Augusts. Optimal temperature is $28-35^{\circ} \mathrm{C}$.

\section{Discussion}

The oat genus, Avena, is a typical example. Some species of this genus are among the world's worst and most abundant weeds, other species are rare and endangered taxa restricted to a few islands. In a simple sum of all wild oat populations, the rare and interesting taxa would be swamped. Autogamy and apomictic species can multiply relatively few genotypes over large areas. The population sizes of such species could mislead as indicators of their standing genetic diversity $[4,5]$.

Wild species are growing as weeds and in natural habitats and play big role in species formation processes. Two species of oats: A. fatua and A. sterilis subsp. ludoviciana are considered as close relatives of cultivated oats on the base of chromosome number and species-specific fungal disease are form separate group and are considered as well as close relative plants of $A$. sativa [11]. Oats - A. fatua has this species could be of importance in breeding programmed for the cultivated oats (A. sativa), where it could confer drought tolerance, disease resistance and higher yields. Oats are in general easily grown plants but, especially when grown on a small scale, the seed is often completely eaten out by birds. Some sort of netting seems to be the best answer on a garden scale. A. fatua is a species of grass in the oat genus. It is known as the common wild oat.
A. sterilis subsp. ludoviciana has the seed ripens in the latter half of summer and, when harvested and dried, can store for several years. It can be used as a staple food crop in either savory or sweet dishes. The seed can be cooked whole, though it is more commonly ground into a flour and used as a cereal in all the ways that oats are used, especially as a porridge but also to make biscuits, sourdough bread etc. The seed can also be sprouted and eaten raw or cooked in salads, stews etc. The roasted seed is a coffee substitute. Common oat is the most demanding cultivated variety of this crop as regards daylight duration. Northern cultivars need for their development longer daylight than southern ones. With 14 hours of daylight they do not head. The analysis of the harvest structure with oat cultivars grown at different photoperiods revealed longer stalks and panicles, a greater number of seeds and a higher overall weight with plants grown at shorter daylight. However, since under such condition's oat panicles emerge much later than otherwise, the seeds have no time to mature properly and are hollow. These species are weedy plants mixed with grain corns in the field [12].

A. barbata has a cultivated species of A. sativa var. aurea and it is crops in Georgia. Other is a species as A. sterilis and it makes as accords of A. sativa var. krausei [2]. Occurs on stony slopes, in loams, in sands, in meadows, along riversides and is as a ruderal species of plant in fields. Also occurs in plains and at the lower mountain level and in cultivated beds. Occurs is along roads, in settlements, and in fields. The roasted seed is a coffee substitute. Seeds sow in situ in early spring or in the autumn. Only just cover the seed. Ex situ conservation of this species will be effective to collect seeds and keep in seed banks. The local population and governmental bodies responsible for the nature protection should be informed about high conservation value of this species [5].

Treatment is used for oats in meal with ground surface and uneven grains. Oats contain magnesium that is necessary for the cardiovascular, nervous system and metabolism. This plant also contains amino acids, including glutamine acid, is rich in vitamins $\mathrm{E}$, D, PP, B1, B2, B3, B6. The use of protein markers permits successful identification of genetic resources and registration when solving different problems related to classification of cultivated plants and their wild relatives. A study of protein markers of the cultivated hexaploid oat $A$. sativa, cultivated diploid species

\section{Conclusion}

Avena has a CWRs as should understand all species related to any cultivated plants, as well as to wild species of ornamental, food, fodder and forage, medicinal plants, condiments, forestry species and plants used for industrial purposes, such as oils and fibers i.e. to all plants of economic importance. Although, "classical" definition of CWR is restricted only to species related to cultivated crops, including such important field crops as A. sativa, A. sativa var. aurea and A. sativa var. krausei. CWRs are to species $A$. fatua, A. sterilis subsp. ludoviciana, A. sterilis and A. barbara. Other Avena 2 species are in Georgia and has not for cultivated crops $A$. clauda and A. ventricosa. 


\section{References}

1. Akhalkatsi M (2015) Erosion and Prevention of Crop Genetic Diversity Landraces of Georgia (South Caucasus). Genetic Diversity and Erosion in Plants. Springer International Publishing 7: 159-187.

2. Ketskhoveli N (1957) Zones of cultivated plants in Georgia. Georgian Academy of Sciences Press, Tbilisi, Georgia.

3. Zhizhilashvili K, Berishvili T, Baiashvili E, Shanshiashvili T, Gorgidze L (1987) Study of Tusheti cultural flora. Institute of Botany of the Academy of Sciences of Cultural Flora Division, Tbilisi, Georgia.

4. Vavilov NI (1992) Origin and geography of cultivated plants. SanktPetersburg, Nauka, pp. 498.

5. Akhalkatsi M (2009) Conservation and Sustainable Use of Crop Wild Relatives in Samtskhe- Javakheti. Final Report. Tbilisi, Elkana, Georgia.

6. Akhalkatsi M (2015) Crop Wild Relatives of Georgia. In: Alexsidze G (Edt.), Agrobiodiversity of Georgia (Catalog). Georgia Academy of Agricultural Sciences, Georgia, pp. 183-216.
7. Maxted N (2008) Recovery, Conservation, and Sustainable Use of Georgia's Agrobiodiversity. Terminal Evaluation. Tbilisi, Elkana, Georgia.

8. Grossheim AA (1939) Flora of Caucasus. V.2. Polypodiaceae Gramineae. Baku Publishing house AzFaN. Azerbaijan, pp. 587.

9. Javakhishvili, I (1930) Sakartwelos ekonomikuri istoria (Economic History of Georgia). v. 1. Tbilisi, Georgia.

10. Makashvili A, Sosnovski L (1941) Georgian Flora. V.2 Georgian Academy of Sciences Press, Tbilisi, Georgia.

11. Pistrick K, Akhalkatsi M, Girgvliani T, Shanshiashvili T (2009) Collecting plant genetic resources in Upper Svaneti (Georgia, Caucasus Mountains). Journal of Agriculture and Rural Development in the Tropics and Subtropics Supplement 92(Suppl): 127-135.

12. Akhalkatsi M, Girgvliani T, Mazanishvili L (2018) Crop Wild Relatives of the Hordeum L. Genus in Georgia (South Caucasus). Agri Res \& Tech: Open Access J 14(2): 1-6.

\section{Your next submission with Juniper Publishers will reach you the below assets}

- Quality Editorial service

- Swift Peer Review

- Reprints availability

- E-prints Service

- Manuscript Podcast for convenient understanding

- Global attainment for your research

- Manuscript accessibility in different formats

(Pdf, E-pub, Full Text, Audio)

- Unceasing customer service

Track the below URL for one-step submission https://juniperpublishers.com/online-submission.php 